\title{
Razvoj makroekonomije i rezolutivno-kompozitivna metoda
}

\author{
JOSIP LUČEV \\ Fakultet političkih znanosti, Sveučilište u Zagrebu
}

\begin{abstract}
Sažetak
Cilj je ovog teksta pokazati svrhovitost upotrebe hobsovske rezolutivno-kompozitivne metode kao uporišta za analizu povijesti moderne ekonomske misli, a naročito makroekonomije. Najprije se obrazlaže važnost rezolutivno-kompozitivne metode u djelu Daga Strpića. Zatim se pokazuju osnovna obilježja stiliziranih pomaka u paradigmama ekonomske misli (neoklasična ekonomija - kejnzijanska ekonomija - slobodnotržišna paradigma) koji u svjetlu ove reinterpretacije dobivaju strukturu rezolucije-kompozicije-rerezolucije. Nudi se i interpretacija povijesti ekonomske znanosti "nakon Hayeka" kao perioda dominacije kompozitivnog elementa, odnosno kejnzijanskih makroekonomskih koncepata koji se oslanjaju na agregate. Objašnjavaju se neoklasična sinteza i osnovne metodološke dvojbe koje je dugotrajna integracija Keynesa $u$ mainstream pretpostavljala (uključujući izbor između agregata i agregiranih pojedinaca u osnovi konceptualizacije makroekonomije). Problematizacijom tih dvojbi prate se komplementarni odnosi dugog roka, pretpostavljene racionalnosti aktera i optimalnih slobodnotržišnih rezultata. Prikazuje se i stanje znanosti na kraju 20. i početku 21. stoljeća, odnosno Lucasovo metodološko zaoštravanje Friedmanovih ideja, kao i dovršeni oblik tog idejnog sklopa u okviru "teorije realnih poslovnih ciklusa". Ponovna dominacija rezolutivnog elementa (slobodnotržišna paradigma) koji konstituira ideju samoregulativnog tržišta oko savršeno racionalnog pojedinca dovodi nas u stvarne poteškoće: redukcija na savršeno racionalnog pojedinca (rezolutivni manevar) ne bi smjela konstituirati veću cjelinu kompozitivno ukoliko je ta redukcija nerealistična na način koji dramatično ograničava samu korisnost teorije. Stoga se zaključno otvara i pitanje primjene ovih ideja na predviđanje kriza i formuliranje odgovora na njih.
\end{abstract}

Keywords: makroekonomija, povijest ekonomske misli, racionalnost, problem agregiranja, rezolutivno-kompozitivna metoda, Strpić 


\section{1) Uvod}

Male, ali temeljne razlike u pristupima društvenih znanosti mogu uzrokovati velike diskrepancije u policy preporukama koje tipično slijede iz njih. Ekonomska znanost u sebi skriva iznimno bogatu strukturu škola i pristupa, iako ju je teško nazrijeti kroz naoko monolitno zdanje mainstreama. Razni suprotstavljeni pristupi mogu supostojati istovremeno, ali su kontrasti još zornije vidljivi ako uzmemo u obzir njihov povijesni razvoj. Cilj ovog teksta je na analizu tog razvoja primijeniti specifičan element političko-ekonomske analize Daga Strpića, tj. rezolutivno-kompozitivnu prizmu. Ujedno na taj način možemo odgovoriti na neka otvorena pitanja povezana sa Strpićevim radom. Naime u dosadašnjoj diskusiji nakon objavljivanja Strpićeve disertacije ${ }^{1}$ nametnula su se dva relevantna pitanja. Prvo se pitanje odnosi na izbor polazišta analize u Strpićevim radovima - odnosno logiku izvođenja političko-ekonomske analize počevši od Thomasa Hobbesa. Drugo pitanje odnosi se na logiku završavanja takve analize s Hayekom. Ono je kompleksnije, te se cilj ovog rada može suziti na pokazivanje svrhovitosti nastavljanja s analizom orijentiranom na kompoziciju i rezoluciju i nakon Hayeka.

U idućem odjeljku nudi se reinterpretacija rezolutivno-kompozitivne metode kao instrumenta za dekodiranje suvremenih izazova u ključnim dilemama ekonomske znanosti i izlaže se osnovna argumentacija. Iako se pojmovi rezolucije i kompozicije ne nalaze u uobičajenom kategorijalnom aparatu današnje ekonomske znanosti, u tom će se odjeljku pokazati zašto se blago zaoštreni oblik razlikovanja tendencija rezolucije i kompozicije može koristiti za daljnju analizu. U trećem odjeljku se prikazuje funkcioniranje tog argumenta u analizi kompozitivnog i kejnzijanskog razvoja makroekonomije "nakon Hayeka". Zatim se u četvrtom odjeljku otvaraju četiri dileme kroz koje se u prvih nekoliko desetljeća nakon Drugog svjetskog rata kejnzijanska misao reinterpretirala i nadograđivala u kontekstu spajanja kejnzijanske makroekonomije i neoklasične mikroekonomije. Ta je polagana preobrazba makroekonomije provedena kroz utjecaje znanstvenih opredjeljenja $\mathrm{u}$ smjeru reprezentativnih agenata, višestruke modelske orijentacije na dugi rok te izbora agregirane ravnoteže umjesto agregata kao osnovne konceptualizacije makroekonomije. U tom će se odjeljku pokazati učinci dugoročne orijentacije na mikroekonomske efekte tržišta (odnosno suočavanja s učincima na tržišni rezultat), na makroekonomske ishode i implikacije tržišno optimalnih rezultata te konačno na

${ }^{1}$ Ova se diskusija prvenstveno odvijala u kontekstu okruglog stola "Marxovo znanstveno nasljeđe (1818-2018)" održanog 10.-11. 5. 2018. s izlaganjima Tomislava Badovinca, Bogomira Kovača, Dragutina Lalovića, Đure Medića, Matka Meštrovića, Zdravka Petaka, Luke Ribarevića, Domagoja Vujeve i Zorke Zović Svobode, predstavljanja knjige Daga Strpića (2017) na 11. subversive forumu 17. svibnja 2018. s izlaganjima Dragutina Lalovića i Bogomira Kovača te rasprava povezanih s izlaganjima na oba događaja. 
odnos nezaposlenosti i inflacije. Na osnovi potonjeg pitanja istaknuta je i simbolička prevlast Friedmanove slobodnotržišne paradigme nad već parcijalno probavljenom kejnzijanskom ili, držeći se postavljene analogije - faza rerezolucije početkom 1970-ih smijenila je fazu kompozicije. U petom se odjeljku analizira stanje mainstream ekonomske znanosti od Friedmana nadalje - krajem 20. i početkom 21. stoljeća (dakle neposredno prije velike krize 2008/2009). U šestom odjeljku prikazuje se uloga rezolutivnosti kao metodološkog individualizma u suvremenim pristupima u kontekstu "Međunarodne političke ekonomije" i formuliranja antikrizne ekonomske politike, a u zadnjem se odjeljku iznose zaključne napomene.

\section{2) Dag Strpić, rezolucija/kompozicija i njezina primjena na razmatranje povijesti ekonomske analize}

Prvo pitanje naznačeno u uvodu relativno je jednostavno jer se odgovor o važnosti Hobbesa skriva u Strpićevoj metodologiji. Strpić tako u svakom svom objašnjenju klasične političke ekonomije kreće od Thomasa Hobbesa. To je bio slučaj u njegovoj disertaciji iz 1991. godine, objavljenoj 2017. godine kao Robna proizvodnja i udruženi rad u Marxovoj kritici političke ekonomije (Strpić, 2017: 25-35), u njegovoj prvoj objavljenoj knjizi - Promjena: Od Hobbesa do Hayeka (Strpić, 1998: 7-19), na brojnim usputnim mjestima (pr. Strpić, 2015: 18; 2010: 16-20), ali i u Strpićevu dizajnu kolegija Politička ekonomija koji se niz godina održavao na drugoj godini preddiplomskog studija Politologije na Fakultetu političkih znanosti Sveučilišta u Zagrebu. U osnovi Strpićeva korištenja Hobbesa logički je i metodološki rezolutivno-kompozitivni manevar velikog klasika. Polazeći od Macphersona (1962), Strpić ga definira kao postupak "kojim se cjelina predmeta istraživanja najprije analitički razlaže na najmanje dijelove koji još zadržavaju odredbe pripadnosti toj cjelini, a onda se cjelina ponovo iz njih komponira tako da zakonitosti njezine konstitucije i funkcioniranja budu jasno uočljivi" (Strpić, 2017: 30). Radi se o izuzetno važnoj metodi s obzirom na to da se preko nje dolazi do Hobbesova pojma građanskog društva, oformljenog preko društvenog ugovora (ibid.: 28). Izlazak iz prirodnog stanja koji se tako ostvaruje (logički, a ne povijesno) zapravo je eksplicitni kompozitivni dio metode, dok se rastavljanje društva na pojedince kao rezolutivni dio metode samo implicira (ibid.: 32). Za Strpića je takav manevar presudan u njegovu vlastitom istraživačkom projektu (ibid.: 18), iako se na prvi pogled čini da se radi o osnovnom znanstvenom opredjeljenju. Tako "prevedeno na jezik ekonomije, privatni pojedinac, kao polazište teorijske analize, vodi [...] podjednako liberalnim i intervencionističkim konzekvencama" (ibid.: 30), pod čime možemo shvatiti da oba tipa pristupa (liberalni i intervencionistički) mogu imati ishodište $u$ pojedincu, odnosno da svaki tip teorije mora imati i predodžbu o individualnim akterima i širim skupovima koje oni grade - pa se neovisno o konačnim posljedicama 
može početi od pojedinca. No, uz blago zaoštravanje te teze, moramo zamijetiti da postoje osnovne metodološke razlike u najvažnijim ekonomskim (i političko-ekonomskim) školama koje upućuju na njihove intervencionističke ili liberalne posljedice. $\mathrm{U}$ ovom će se radu prikazati upravo taj tip osnovnih razlika - s fokusom na njihovu (pre)opterećenost rezolucijom ili kompozicijom.

Skica 1 prikazuje ključne tri faze ekonomskog/političko-ekonomskog mainstreama od sredine 19. stoljeća do danas.

Skica 1. Rezolutivni i kompozitivni fokusi 19, 20. i 21. stoljeća

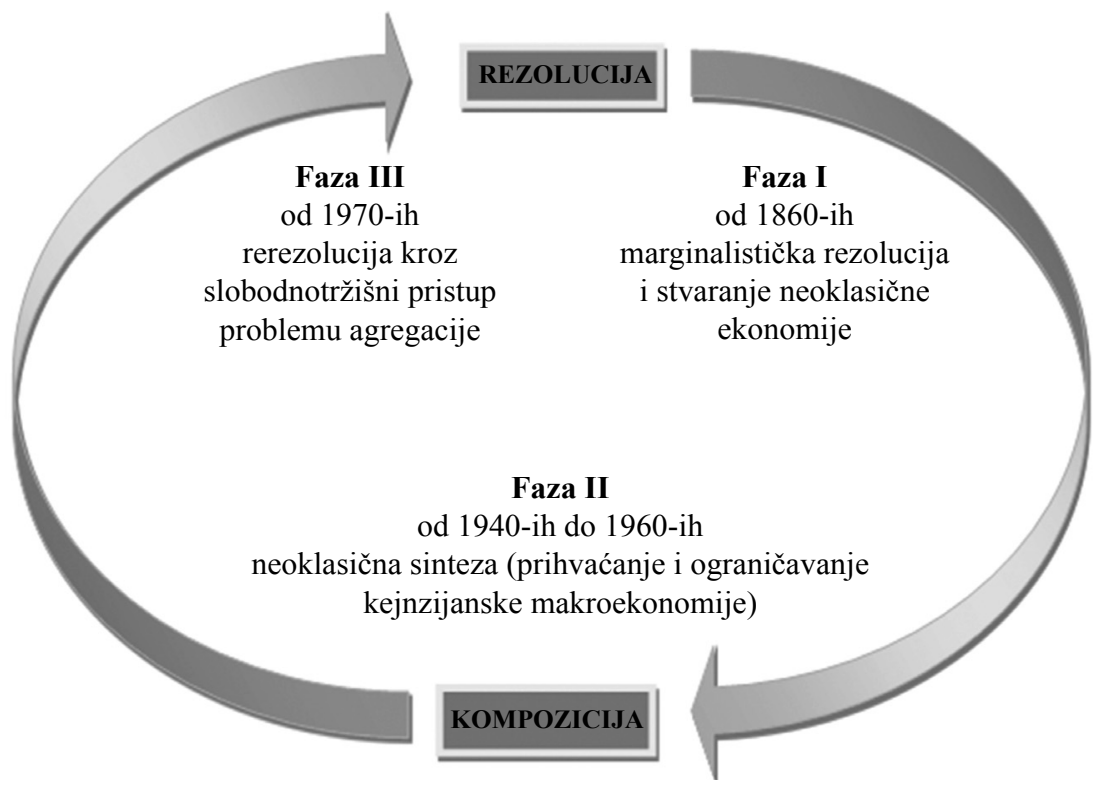

Na skici je pod oznakom Faza I prikazan period marginalističke revolucije (1860-e i 1870-e) koji će se stabilizirati krajem 19. stoljeća u mainstream zdanju neoklasične ekonomije. U tom se periodu razvijaju ključni elementi suvremene ekonomske znanosti, i stoga je važno polazište za daljnji razvoj. Na skici je označena pod nazivom "rezolucija" jer je to period u kojem je izniknula mikroekonomija. Primarni kategorijalni aparat suvremene ekonomije tako je postao prvenstveno naslonjen na pojedinačna tržišta, teoriju potražnje koja ovisi o individualnoj aktivnosti i graničnoj korisnosti te teoriju ponude koja ovisi o individualnom optimiziranju. Faza II prikazuje period dominacije kejnzijanske škole u ekonomiji. Označena je nazivom "kompozicija" jer je to period pojavljivanja makroekonomije, koji je u neoklasični mainstream asimiliran kroz "neoklasičnu sintezu" 1940-ih. Kroz makroekonomiju se ekonomija počinje promatrati kao agregat, pa su temeljne kategorije 
sada otvorene za operiranje sa sveukupnom ili agregatnom potražnjom i ponudom, a ne više samo s teže opazivim i modelski zamišljenim individualnim ponašanjem. Konačno, Faza III opisuje period nakon čikaške proturevolucije (od 1970-ih) kao rerezoluciju, budući da se tada paradigmatska mainstream pozicija ekonomske znanosti ponovno naglašeno okreće pojedinačnim akterima i njihovu ponašanju. Zaoštravaju se već prisutne tendencije redefiniranja same makroekonomije kroz agregiranje individualnog ponašanja (umjesto jednostavnog operiranja s agregatima). Iz skice je razvidno da su prva i treća faza slobodnotržišne i rezolutivne, dok je druga faza intervencionistička i kompozitivna. U nastavku rada podcrtat će se odnosi između te dvije suprotstavljene tendencije. U njihovoj se osnovi nalaze razne strategije razrješenja odnosa između mikroekonomije i makroekonomije kao osnovnoga pojmovnog i metodološkog pitanja ekonomije kao znanosti.

Termini rezolucije i kompozicije danas se čine pomalo anakronističnima, nadomjestili su ih drugi termini upućeni na postizanje/nadvladavanje metodološkog individualizma (pr. problem agregiranja, microfoundations, opća ravnoteža). Preko njih problem rezolucije i kompozicije otvara ključna pitanja razvoja ekonomske znanosti u posljednjih sedam desetljeća, kojima će se baviti nastavak ovog rada. Ta pitanja uključuju promjene u shvaćanju same makroekonomije, modele dinamičke stohastičke opće ravnoteže (DSGE), antikrizne politike i mjere štednje, kao i ključne razlike u današnjim pristupima međunarodnoj političkoj ekonomiji. Pokazat ćemo da se radi o središnjim prijeporima u ekonomiji usprkos tome što nisu tradicionalno poznati pod rezolutivno-kompozitivnim nazivima. Iako se dakle mainstream ekonomije ne služi nužno tim terminima, 20. i 21. stoljeće uvelike je obilježio problem agregiranja, koji stoji ne samo između mikroekonomije i makroekonomije nego i u osnovi metodoloških pristupa u današnjoj međunarodnoj političkoj ekonomiji. Razvoj mainstreama makroekonomije upravo se i može pratiti kroz odnos prema rastavljanju gospodarstva na "njegove osnovne dijelove (njegovu strukturu), povezanosti različitih tržišta [...] te ponovnom agregiranju makroekonomije kako bi se postigla cjelokupnost" (Fine i Dimakou, 2016: 2). Današnji mainstream je rezultat razvoja koji se nakon kejnzijanske strategije jednostavnog kretanja od agregata (kompozicija) vratio na mikroekonomski nadahnutu analizu koja agregat rekonstituira iz pojedinca (rezolucija). ${ }^{2}$

${ }^{2}$ U tome leži lagano zaoštravanje koncepta rezolucije i kompozicije. Analogija koja bi bila u potpunosti vjerna rezolutivno-kompozitivnoj metodi vjerojatno bi tek u mikroekonomskom skretanju makroekonomije današnjeg mainstreama vidjela puni rezolutivno-kompozitivni ciklus. No ovaj se tekst zalaže za reinterpretaciju tih koncepata na način koji omogućuje proučavanje velikih promjena $\mathrm{u}$ ekonomskoj znanosti s obzirom na promjenjivi fokus mainstreama (rezolucija-kompozicija), pa samim time postaje zanimljivom metodološka tendencija prema rezoluciji ili prema kompoziciji. 


\section{3) Nakon Hayeka: kompozicija i njezini problemi}

U istraživanju povijesti ekonomske znanosti nakon Hayeka prvenstveno je važno definirati što odrednica "nakon Hayeka" uopće može značiti. Očito je da u spomenutom kontekstu ne može biti doslovna jer Hayek umire 1992, nego konceptualna, utoliko što Hayek zagovara rješenja koja proizlaze iz predkejnzijanske ere. Austrijska škola, čiji je Hayek jedan od najpoznatijih predstavnika, proizlazi iz radova Carla Mengera, dakle iz jednog od tri marginalistička pravca 1860-ih i 1870-ih - uz Jevonsov i Walrasov - koji tvore osnove današnje neoklasične ekonomije (Schumpeter, 1975: 797-799). Mengerovu misao nastavljaju brojni “Austrijanci”, u prvom redu Böhm-Bawerk i Mises. Hayekove se osnovne interpretacije naslanjaju na njih, ali i na Wicksellov (pripadnik Stockholmske škole, i sam očito nadahnut ranijim fazama Austrijske škole) pristup krizama. Iz tog se razloga Hayekova teorija kriza ispravnije naziva Wicksell-Mises-Hayekovom teorijom. Dok će Hayek još godinama stvarati i artikulirati svoje ideje, u tom se pojavnom obliku najizravnije nametnuo kao Keynesov sugovornik, a upravo u tim svojim osnovama prvenstveno predstavlja izrazito zaoštren oblik predkejnzijanske, neoklasične misli. Ona izrazito i eksplicitno prianja upravo uz metodološki individualizam (Strpić, 1998: 92-98) koji je u temeljima rezolucije, kako je interpretirana u ovom tekstu. Zajedno s neoklasičnim mainstreamom koji predvodi Alfred Marshall, Hayek osnove svoje analize traži u pojedincu. U samoj neoklasičnoj ekonomiji razvija se mikroekonomija koja se fokusira na pojedince i pojedinačna tržišta i poduzeća, pa se za tu fazu može tvrditi da se fokusira na rezoluciju. "Nakon Hayeka" se dakle odvija dinamika prikazana u Skici 1 kroz faze II i III. Radi se o prihvaćanju Keynesa u mainstream i njegovu sporom probavljanju (kroz tzv. neoklasičnu sintezu) sve do trenutka kada ga se nadomješta u paradigmatskom smislu otvorenijim zaokretom prema slobodnom tržištu u 1970-ima. Taj se otvoreniji zaokret u literaturi različito naziva prema odabranom fokusu, naglasku i ideološkoj opterećenosti - evocirajući specifične škole terminima monetarizam, nova klasična ekonomija ili čikaška proturevolucija, a paradigmatski zaokret terminima neoliberalizam, slatkovodna ekonomija, ${ }^{3}$ ali i jednostavno neoklasična ekonomija (za pregled vidjeti Lučev i Babić, 2013). U svakom se slučaju radi o povratku na početnu slobodnotržišnu poziciju, pa je tako kejnzijanski paradigmatski period s obje strane omeđen slobodnotržišnim paradigmama na neoklasičnim osnovama (dakle do 1930-ih i od 1970-ih), a usprkos razvoju znanosti obje verzije metodološki inzistiraju na ulozi pojedinca. Važno je dakle razgraničiti Keynesa kao iznimku.

3 Slatkovodna ekonomija ili freshwater economics je referencija na prvotni izazov slobodnotržišne paradigme kejnzijanskoj. Taj je izazov igrom slučaja upućen sa sveučilišta koja su geografski blizu Velikim jezerima (a od kojih je najvažnije Sveučilište u Chicagu), dok se kejnzijanska misao nešto duže održala na sveučilištima poput Harvarda, Princetona ili Stanforda uz zapadnu i istočnu obalu SAD-a (što daje oprečnu oznaku saltwater economics). 
Osnovna distinkcija kejnzijanske misli skriva se u pitanju stvarne uloge makroekonomije. Udžbenički se "izum" makroekonomije pripisuje Johnu Maynardu Keynesu zbog njegova inzistiranja na agregatnoj potražnji (Keynes, 1936/2013, 1937), usprkos tome što takvo pripisivanje preskače niz drugih autora ${ }^{4}$ i što Keynes nikada nije koristio termin "makroekonomija" (Hoover, 2008: 318). No njegov je fokus na agregate bio očit i eksplicitan. Kako je sam naglašavao, ne zanimaju ga pojedinačni sektori, poduzeća ili pojedinci, nego gospodarski sustav kao cjelina, i to kroz "agregatni dohodak, agregatnu dobit, agregatni output, agregatnu zaposlenost, agregatnu štednju" (Keynes, 1936/2013: xxii). Utoliko mu se može pripisati i usredotočenost na kompoziciju, budući da ga zanima tek konačni rezultat cjelovitoga gospodarstva. No to ne znači da nije svjestan pojedinca, pa čak i kompleksne, heterogene prirode raznih pojedinaca okupljenih u gospodarstvo (Dasgupta, 2002: 74; Hoover, 2008: 318). To znači samo to da je Keynes svjesno napravio kompozitivni korak kako bi s takvim novim fokusom bolje mogao interpretirati djelovanje gospodarstva.

Tako je omogućen novi uvid u agregatnu ponudu i potražnju, a to je omogućilo konceptualizaciju ekonomskih kriza kao krajnje nesavršenih ishoda funkcioniranja tržišta - budući da agregatna potražnja može posrnuti daleko ispod razine agregatne ponude. Takvo je tumačenje u praktičnom smislu prvenstveno bilo usmjereno na antikrizno djelovanje. Na temelju osnovne logike gospodarstva kao agregatne potražnje bilo je jasno vidljivo da su krize iracionalni trenuci u kojima raspršene privatne odluke pojedinaca i poduzeća doprinose kontrakciji, pa se takav pad mora nadoknaditi kroz druge elemente, a često najelegantnije kroz fiskalne poticaje - tj. kroz povećanje javnih rashoda (Akerlof i Shiller, 2009; Krugman, 2012). Zbog logike međusobne povezanosti kroz agregate, iz Keynesove metodologije proizašla je legitimacija velike, regulacijski i intervencionistički nastrojene države orijentirane na redistribuciju i obuzdavanje kriza.

Zaokret u fokusu bio je znatan i utjecajan, pa su se ubrzo pojavili pokušaji njegova pomirenja sa starim mainstreamom. Keynes umire već 1946. te nema izravan utjecaj na način korištenja svojih ideja u periodu njihova najvećeg utjecaja (okvirno 1945-1973). Jedan od najvažnijih elemenata takvog pomirenja bio je formalniji pristup problematici kroz klasični Hicksov ISLM graf, koji objedinjuje kretanja štednje, investicije i likvidnosti (Hicks, 1937), pa je isti uvelike označio verziju kejnzijanizma uvriježenu u mainstreamu. Preferencija formalne analize dodatno će se zaoštriti kroz "formalističku revoluciju” kasnih 1940-ih i 1950-ih u kojoj su ma-

4 Tako se zaobilaze nastojanja ranijih autora da zahvate gospodarstvo u cjelini, najzamjetnije Françoisa Quesnaya (Tableau économique) i ostalih fiziokrata, kao i Leona Walrasa i ideje opće ravnoteže. 
tematički modeli preuzeli primat u ekonomskoj analizi, ${ }^{5}$ čineći formu ekonomskih argumenata najvažnijim aspektom (Blaug, 2003: 145-146). Još važnije, makroekonomiju se vrlo brzo počelo redizajnirati definiranjem njezinih microfoundations ili mikrotemelja (odnosno pomicanjem fokusa na rezoluciju). Na tim je osnovama Keynesova makroekonomija udružena s neoklasičnom mikroeokonomijom kako bi se proizvela "neoklasična sinteza" (Blanchard, 1991). Primarni je Keynesov fokus kroz takav proces ipak donekle izgubljen, pa tako neoklasičnu sintezu Joan Robinson slavno naziva bastardnim kejnzijanizmom (Foley, 2014: 11). Rezultat je bilo rješavanje problema agregiranja na osnovi zbrajanja pojedinaca (kao mikrotemelja) u ravnoteži, a ne više jednostavnog bavljenja agregatima. Tako je integralni element neoklasične sinteze postala opća ravnoteža kao alternativni dizajn makroekonomije. Taj se izazov kejnzijanskoj misli može interpretirati kao korak unazad u agregaciji i kao početak ponovnog otvaranja pitanja prirode makroekonomske analize (ili, rječnikom Macphersona i Strpića, kao tendencijski zaokret od naglaska na kompoziciju prema naglasku na rezoluciju). U idućem će se odjeljku detaljnije pokazati kako je izvedena takva integracija kejnzijanskog pristupa agregiranju kroz neoklasičnu sintezu. U nastavku ću se pozabaviti fazom rerezolucije i teorijama u primjeni u kontekstu međunarodne političke ekonomije i kriza.

\section{4) Probavljanje i zaobilaženje kejnzijanske kompozicije: agregati, rokovi i tržište}

Ovaj će odjeljak prikazati četiri specifične dileme koje su nastale u kontekstu interakcija neoklasične i kejnzijanske ekonomije. Najprije će se otvoriti pitanje konceptualizacije tržišta i tržišnih rezultata u mikroekonomiji i pokazati presudnost izbora kratkog ili dugog roka proučavanja. Zatim će se prikazati ključne konceptualne dileme makroekonomije i utjecaj osnovnih metodoloških postulata na optimizam ili pesimizam u odnosu prema slobodnom tržištu, kao i (ponovno) učinak opredjeljenja za kratki ili dugi rok u makroekonomskom proučavanju. Konačno će se pokazati i simbolički trenutak eksplicitnog nadvladavanja kejnzijanske škole kroz Friedmanov rad na Phillipsovoj krivulji. Taj rad pokazuje i razne aspekte svih ostalih prikazanih dilema, ali pogotovo učinak odabira dugog roka.

${ }^{5}$ Leijonhufvud (1973) će se na duhovit način osvrnuti na formalističku revoluciju u kvaziantropološkom eseju "Life Among the Econ", gdje pristupa opisu plemena Econ (profesionalnih ekonomista) koje podozrivo gleda na srodna plemena Polsci i Sociog (politologa i sociologa). U plemenu Econ se društveni status određuje prvenstveno kvalitetom "modla" (modela) koji mogu izraditi, pa se svećenička kasta Math-Econ odnedavna profilirala kao hijerarhijski najviša zbog najceremonijalnijih i najukrašenijih "modla" koje znaju izraditi. 


\subsection{Savršena ili nesavršena pojedinačna tržišta - utjecaj dugog roka?}

Neoklasična ekonomija naslonjena je na koncept savršenih tržišta koji ovisi o tržišnoj strukturi savršene konkurencije, iako je sama po sebi, dakako, daleko šira i suptilnija. No čak i u momentima u kojima se nesavršenosti tržišta priznaju, primjena dugog roka približava nas ponovno očekivanjima optimalnih tržišnih rezultata. Veliko konceptualno unaprjeđenje tržišnih struktura predstavljali su doprinosi Joan Robinson i Edwarda Chamberlina (Robinson, 1933/1969; Chamberlin, 1933/1962) kroz koje se među neoklasična zamišljanja stanja tržišta ugradila realističnija konceptualizacija. Tako se između tržišnih struktura kakve je opisao Marshall - dakle između savršene konkurencije (idealnog stanja tržišta) na jednom polu i monopola/ oligopola (izrazito prepoznatljivih i nesavršenih stanja tržišta) na drugom - pojavio novi opis monopolističke konkurencije koji daleko bolje opisuje normalno i očekivano stanje tržišta od savršene konkurencije. Za razliku od monopolističke, savršena konkurencija naime pretpostavlja da su svi proizvodi na danom tržištu identični (homogeni - pa je samim time reklamiranje nemoguće jer bi uvelo određeni tip diverzifikacije), da su svi akteri savršeno informirani (npr. o svim trenutnim cijenama na tržištu i njihovim budućim kretanjima) i racionalni, pa čak i da je nemoguće ostvariti profit iznad normalnog profita (tj. oportunitetnog troška kapitala). Iz tog je razloga savršena konkurencija opis tržišta u kojem postoji bezbroj atomističkih aktera (dakle nema većih poduzeća), a ne svijet koji bismo lako prepoznali. Monopolistička konkurencija je pak opisala stanje tržišta u kojem postoje reklamiranje proizvoda, profit i korporacije, odnosno konceptualizaciju kroz koju je moguće zamisliti tržište kao nesavršeno. No uvođenjem dugog roka oba su uvida ublažena, a tržište shvaćeno kao dugoročna tendencija prema optimumu. To ublažavanje implicitno je već u izvornim tekstovima, pa je tako jedna od sličnosti Robinson i Chamberlina upravo dugoročnost kao uzrok nulte stope profita (Archibald, 2018: 9089). Radi se o posljedicama pojavljivanja više konkurenata s protokom vremena. Reagirajući na postojanje profita, drugi poduzetnici će emulirati proizvod monopolističkog konkurenta, nuditi supstitute i tako smanjivati njegov tržišni udjel. Tako se s vremenom prosječni prihod izvornog proizvođača nužno modelski približava prosječnom trošku. Drugim riječima, nastavljanjem pojavljivanja konkurenata smanjuje se njegov ekonomski profit sve dok ne nestane (za standardne udžbeničke pristupe vidjeti Babić, 2015: 209-212; Samuelson i Nordhaus, 2009: 191-193). Tako se tim manevrom dugog roka implicitno ponovno uvode neki elementi savršene konkurencije: izostanak ekonomskog profita, savršena racionalnost (jer se konkurenti pojavljuju dok god ima profita) i neke značajke homogenosti proizvoda (jer se od konkurenata očekuje da preotmu sav ekonomski profit - dakle bez mogućnosti da postojeće brendiranje predstavlja prepreku). Samim time s protokom vremena se cijena približava društveno optimalnoj. 


\subsection{Priroda makroekonomije: agregat ili opća ravnoteža?}

Devetnaesto je stoljeće naslijeđe Leona Walrasa i njegova razmišljanja o općoj ravnoteži ostavilo nepotpuno iskorištenim. Kasniji Keynes razmišljao je u kontekstu agregata (konačni zbroj, a ne identificiranje/rekonstrukcija individualnih aktera s ciljem emuliranja takvog zbroja u ravnoteži). Početkom stoljeća je dakle valrasovska logika opće ravnoteže zanemarena, no već 1940-ih i 1950-ih nameće se kao centralni okvir ekonomije (Backhouse, 2002: 254; Janssen, 2018: 8745) kroz neoklasično integriranje Keynesa i već spomenutu formalističku revoluciju. Taj je period dobro predstavljen i Arrow-Debreuovom općom ravnotežom. Tekst koji je objavljen sredinom 1950-ih godina dokazao je da postoji mogućnost savršenog poklapanja agregatne ponude i potražnje pod pretpostavkom savršene konkurencije (Arrow i Debreu, 1954).

Taj doprinos i kasniji radovi Arrowa na istom tragu pokazali su se presudnima za daljnji razvoj mainstream ekonomije. Tako analiza dotadašnje citiranosti u govorima dobitnika Nobelove nagrade za ekonomiju, ${ }^{6}$ provedena 2009. godine, Kennetha Arrowa stavlja na prvo mjesto. To je vrlo pojednostavljena mjera utjecaja, ali može poslužiti kao koristan grub indikator upravo zbog toga što se radi o autorima koje ističu dobitnici najprestižnije nagrade za ekonomiju. Arrow je kumulativno spomenut 37 puta, Hayek je na drugom mjestu s 23, Samuelson na trećem s 20, a Lucas na četvrtom s 18 citata (Skarbek, 2009: 4).

Taj je pomak fokusa s agregata na opću ravnotežu bio presudan jer je omogućio potragu za makroekonomijom na osnovi matematički purističkih reprezentativnih aktera (vidjeti Hartley, 1997), koji se mogu modelirati prema nerealnim pretpostavkama, što može narušiti i njihovu funkcionalnost. Drugim riječima, radi se upravo o obnovljenoj potrazi za microfoundations ili metodološkim individualizmom - $\mathrm{u}$ kojemu se metodološki najprije reducira široke društvene pojave (pa i ekonomske indikatore) na individualnu aktivnost.

\subsection{Savršeno ili nesavršeno nacionalno gospodarstvo - utjecaj dugog roka?}

Primjena logike dugog roka je izuzetno važna i za makroekonomiju. Radi se o razlici između kratkoročne (SRAS - Short Run Aggregate Supply) i dugoročne (LRAS - Long Run Aggregate Supply) agregatne ponude. Ta distinkcija nastaje upravo kroz neoklasičnu sintezu i pokušaje modeliranja kejnzijanskih ideja nešto poznatijim analogijama.

Dugi rok se u makroekonomiji odnosi na period koji je dovoljan da se gospodarstvo prilagodi promjeni u cijenama - a LRAS podrazumijeva interakciju krat-

${ }^{6}$ Preciznije, poznate kao Nagrade Švedske banke za ekonomske znanosti u sjećanje na Alfreda Nobela. 
koročne agregatne potražnje (AD) i kratkoročne agregatne ponude. Primjerice, povećanje javnih rashoda povisi $\mathrm{AD}$, pa se ta krivulja grafički pomiče desno. To nam daje ravnotežnu točku većeg kratkoročnog agregatnog outputa (BDP-a), ali se to postiže samo uz učinak više razine cijena (viša inflacija). Viša razina cijena također sugerira više troškove - a to ima učinak na smanjenje ponude - SRAS se grafički pomiče ulijevo - i to savršeno korespondirajući prvotnom pomaku AD udesno - što daje ponovno ravnotežnu točku na staroj razini outputa uz višu razinu cijena. Isti princip vrijedi i za smanjenje AD (odnosno pomicanje AD ulijevo, koje daje korespondentni pomak SRAS udesno). Tako možemo dobiti samo ravnotežne točke neposredno iznad ili ispod stare ravnoteže. Te nam ravnotežne točke daju grafički izgled LRAS kao vertikalne ravne crte - koja nam sugerira da tržište dugoročno daje output koji nije ovisan o intervencijama ili fluktuacijama u AD. ${ }^{7}$ Ona zapravo odgovara potencijalnom outputu, dakle na dugi se rok ponovno uspostavlja optimalnost tržišnog rezultata. Tržište će, neoklasično-modelski gledano, dugoročno ne samo postići maksimalan rezultat u outputu već i neutralizirati bilo kakve pokušaje intervencije. To je, ukratko, antikejnzijanski konceptualni rezultat neoklasične sinteze u makroekonomiji.

\subsection{Mogućnosti monetarne intervencije: Phillipsova krivulja}

Jedan od važnih alata kejnzijanskog perioda bila je Phillipsova krivulja (Phillips, 1958), koja postulira inverzan međuodnos inflacije i nezaposlenosti. Drugim riječima, taj koncept nastavlja se na kejnzijansku ideju inflacije kao posljedice pregrijavanja gospodarstva - odnosno perioda iznimno niske nezaposlenosti. No takvo je viđenje odnosa između inflacije i nezaposlenosti u mnogome uzdrmano empirijskom situacijom koju nije predviđalo. Sedamdesetih je gospodarstvo SAD-a prolazilo kroz zamjetnu stagflaciju - istovremeno visoke stope inflacije i gospodarsku stagnaciju. U tom je kontekstu dodatnu važnost dobio rad Miltona Friedmana na Phillipsovoj krivulji, koji je mogao objasniti istovremenost te dvije neugodne gospodarske pojave (Friedman, 1968). Friedman ju je tumačio kroz vlastite osnovne postulate o racionalnosti pojedinca, iz čega je izveo zaključak o izlišnosti državne intervencije. Tako državna intervencija može umjetno držati nezaposlenost niskom pod cijenu nešto više inflacije, no inflacija utječe na racionalna očekivanja. Na duži rok se racionalni pojedinci naviknu na višu stopu inflacije, ugrađuju je u svoje planiranje i djelovanje, pa se Phillipsova krivulja efektivno pomiče prema gore (dakle ista stopa nezaposlenosti, ali s višom stopom inflacije). Ako državna intervencija nastavi snižavati nezaposlenost, prouzročit će samo još višu stopu inflacije. Stoga je Friedman govorio o dugoročnoj Phillipsovoj krivulji kao rezultatu adaptivnih očeki-

${ }^{7}$ Za standardne udžbeničke prikaze dugoročne krivulje agregatne ponude vidjeti Mankiw (2017: 428-449) i Dornbusch, Fischer i Startz (2017: 107-117). 
vanja (Friedman i Goodhart, 1975/2003: 55), što je još jedna grafički vertikalna crta koja u ovom slučaju daje prirodnu stopu nezaposlenosti. Taj pristup treba tumačiti u kontekstu ostalih Friedmanovih radova. Oni uključuju značajan zagovor primata upotrebljivosti nad realizmom u ekonomskoj analizi (Friedman, 1953/1966) i utjecajnu analizu povijesti monetarne politike (Friedman i Schwartz, 1963). Sveukupno se kejnzijanski znanstveni projekt našao u značajnoj krizi upravo suočavajući se sa stagflacijom (Robinson, 1972; vidjeti i Kovač, 2018: 260-264), pa se u uspješnom znanstvenom objašnjenju može vidjeti početak paradigmatskog zaokreta prema slobodnom tržištu, počevši s Friedmanovim monetarizmom. Friedman je svakako bio svjestan važnosti upravo tog pitanja, pa je govor prilikom preuzimanja Nobelove nagrade posvetio upravo svom radu na Phillipsovoj krivulji (Friedman, 1976).

U ovom odjeljku prikazana su četiri elementa koja su doprinijela relativizaciji Keynesove logike i zaključaka. S jedne je strane to transformacija osnovnog koncepta makroekonomije napuštanjem kompozitivne logike agregata i usmjeravanjem prema općoj ravnoteži. S druge strane to je kompatibilni višestruki izbor upotrebe dugog roka, koji također čini jednu od ključnih razlika između neoklasične i izvorne kejnzijanske perspektive. Analizirana su i tri slučaja kroz koja upotreba dugog roka konceptualno zaokreće analizu u smjeru tržišnog optimizma. Prvi je prethodio kejnzijanskoj analizi i ticao se profita u tržišnoj strukturi monopolističke konkurencije. Drugi se ticao krivulje agregatne ponude, koja na dugi rok razoružava pomake u agregatnoj potražnji. Nešto preciznije, kroz neoklasičnu sintezu se tako upotrebom dugog roka moglo preformulirati ključan kejnzijanski element na neoklasični način i kooptirati ga u zajedničku strukturu. Treći se slučaj odnosio na trenutak prevladavanja kejnzijanske paradigme, odnosno na Phillipsovu krivulju koja na dugi rok daje vertikalnu prirodnu stopu nezaposlenosti kao ograničenja intervencije, dok god se pretpostavljaju savršeno racionalni pojedinci.

\section{5) Razvoj slobodnotržišne paradigme od 1970-ih: rerezolucija}

Friedman je dao presudan antiintervencionistički poticaj (tzv. čikaška proturevolucija) koji je urodio nadomještanjem kejnzijanske škole monetarističkom kao dominantnom u kontekstu ekonomske znanosti počevši od 1970-ih godina, a mainstream ekonomije je na tom valu postao izrazito slobodnotržišno orijentiran. No daljnji razvoj makroekonomije nije time zaustavljen, nego je jednostavno postao kontekst u kojem su nastajala daljnja postignuća i produbljivanja. Na osnovi dilema prikazanih u prethodnom odjeljku prvo se pojavila Nova klasična škola (kao izravni izdanak monetarizma) koja se temelji na radovima Roberta Lucasa.

Nova klasična škola je dodatno zaoštrila očekivanja racionalnih pojedinaca pomicanjem od Friedmanove ideje adaptivnih očekivanja prema hipotezi savršene racionalnosti (Snowdon i Vane, 2005: 226; Backhouse, 2002: 299). Lucasovi radovi 
isključuju iluziju novca, dakle na osnovi racionalnih očekivanja omogućuju i savršenu informiranost aktera u tom ključnom aspektu (Lucas, 1972: 103). Još važniji je rez postignut jasnijim naglašavanjem koncepta poslovnog ciklusa kao ravnotežnog stanja, u kontrastu s dotada prihvaćenim (izvorno kejnzijanskim) viđenjem kriza kao neravnoteža (Snowdon i Vane, 2005: 236-237). Ta se ravnoteža postiže s obzirom na racionalne reakcije pojedinaca na nepotpune informacije (iako im je, kao što je naznačeno, informiranost u važnom aspektu cijena na mala vrata racionalnih očekivanja ipak omogućena) - moguća je dakle poduzetnička pogreška, ali ne i iracionalnost. U slobodnotržišnim nagnućima Lucas je izuzetno nalik na Friedmana, no njihove su metodološke postavke ipak znatno različite. Friedmanu su se još mogli prigovoriti skriveni kejnzijanski temelji, dok je Lucas izveo dodatnu transformaciju makroekonomije prema općoj ravnoteži (De Vroey, 2010: 2-3) na osnovi neovalrasijanskog razvoja opisanog u prethodnom odjeljku.

Robert Lucas, jedan od najvažnijih ekonomista 20. stoljeća, vidljivost je stekao zahvaljujući i čuvenoj kritici (Ljungqvist, 2018: 8045). Lucasova kritika (ili $L u$ cas Critique) ustvrdila je da nije moguće koristiti povijesne statistike u donošenju ekonomskih policy preskripcija. Naime, povijesni podaci uvijek su pod utjecajem tadašnjih konkretnih javnih politika, pa ponašanje koje mogu zahvatiti ne odgovara budućim kontekstima (Lucas, 1976a: 41-42). Sveukupno Lucasova teorija, kao i Friedmanova, zagovara izostanak kratkoročne stabilizacije u korist dugoročno stabilnih ekonomskih politika (Lucas, 1976b: 8-9), iako to znači da se zapravo krize implicitno shvaćaju kao neproblematične, pa se, dakako, mora naglasiti i potencijalno dobrovoljni aspekt nezaposlenosti (Lucas, 1978: 354).

Iz "Nove klasične škole" izniknut će finalizirana verzija slobodnotržišne makroekonomije kroz "teoriju realnih poslovnih ciklusa" (ili RBC - Real Business Cycle). S ishodištem u tekstu Kydland i Prescott (1982), taj je pristup umjesto monetarnih iznenađenja, koja je Nova klasična škola koristila kao uzroke poslovnih ciklusa, upotrebljavao tehnološke šokove - na koje pojedinačni akteri racionalno reagiraju i daju sliku krize. To je ujedno i jedina velika razlika u usporedbi s Lucasovom teorijom, pa je i "teorija realnih poslovnih ciklusa" ključno naglašavala modele u pozadini općih ravnoteža. Takvim pristupom započinje i upotreba DSGE (dinamička stohastička opća ravnoteža) modela koji će u narednim desetljećima obilježiti primjenu makroekonomije - i to upravo na rezolutivnoj osnovi microfoundations. Do sredine 1990-ih i Lucas će promijeniti mišljenje te prihvatiti važnost realnih poslovnih ciklusa (Snowdon i Vane, 2005: 296). Godine 1970-e i 1980-e obilježila je i transformacija kejnzijanske misli, pa nove kejnzijance obilježava fokus na microfoundations (Romer, 1993: 6) i upotreba opće ravnoteže koja je zahvaljujući Lucasovu utjecaju postala još vidljivijom. Razlika između slobodnotržišne paradigme i novih kejnzijanaca bila je u upotrebi savršene ili nesavršene konkuren- 
cije kao polazišta, ali su metodološke osnove kroz microfoundations postale vrlo slične. To je, uz već opisano neoklasično probavljanje Keynesa, omogućilo vrlo aktivan dijalog teorije realnih poslovnih ciklusa i novih kejnzijanaca kroz opću prihvaćenost DSGE modela, pa neki autori 1990-e opisuju kao novu neoklasičnu sintezu (Dixon, 2018).

Stari kejnzijanizam se implicitno oslanjao na povijesne podatke, pa je tim važniji domet Lucasove kritike koji je temeljnu logiku izokrenuo inzistiranjem na kvalitetnim matematičkim modelima koji mogu biti stvarniji od same empirijske stvarnosti. Lucasova kritika označila je ključni korak u novom valu matematizacije ekonomije, koja svoju upotrebljivost sve više traži u microfoundations, a sve manje u opisima koji odgovaraju dnevnim problemima društva. Lucas je svoju seriju predavanja objavljenu 1987. zaključio pozdravljanjem suvremenih razvoja makroekonomije na osnovi tretmana "agregativnih" problema poput inflacije i kriza kroz prizmu mikroekonomske analize te nadom da će se (kroz dominaciju mikroekonomije) uskoro moći prestati govoriti o mikro- ili makroekonomiji i jednostavno govoriti o ekonomiji (Lucas, 1987: 107-108). U jednom kasnijem govoru Lucas će ustvrditi kako je problem sprječavanja ekonomskih kriza već desetljećima riješen (Lucas, 2003: 1; vidjeti i Chang, 2014). Dakako, radilo se o rješenju (Lucasova kritika) koje je u svojem zaoštrenom obliku jaz između tržišnih nedostataka i matematičkih modela čije ih pretpostavke ne poznaju "rješavalo" s vječnom jasnom preferencijom modela. Nekoliko godina kasnije, iskustvo nepredviđene krize bez jasnih formulacija protucikličkih ekonomskih politika zorno će pokazati koliko je to rješenje bilo problematično. Ne može se u cjelini odbaciti DSGE modele kao antiempirijske, jer su sekvencijski poboljšavani u pokušajima uvažavanja tržišnih nesavršenosti kroz novu neoklasičnu sintezu (Bénassy, 2018), ali i druge doprinose više empirijski orijentiranih modela (primjerice SVAR modela). Ipak, unatoč popravljanjima domet je DSGE modela ostao prvenstveno teorijski unutar pretpostavki koje su pridodane pojedinačnim akterima (Assenmacher, 2017). Lucasova kritika je dakle modele stavila na pijedestal i donekle ih apstrahirala od povijesnih empirijskih podataka. ${ }^{8} \mathrm{Na}$ taj je način savršeno racionalni reprezentativni pojedinac, kojeg

${ }^{8} \mathrm{U}$ tome se ponovila tema mnogo starije rasprave - tzv. Methodenstreit - između Austrijske škole (koja će započeti s Mengerom, a razviti se u konačni oblik s Misesom i Hayekom) i Njemačke historijske škole ekonomije (pr. Sombart, Weber). U toj je raspravi, koja je započela krajem 19. stoljeća, presudno pitanje bila osnovna metoda istraživanja. Austrijska škola tvrdila je da se mogu utvrditi opći obrasci ponašanja, opće zakonitosti koje upravljaju društvenim ponašanjem (današnjim rječnikom takav bismo stav mogli nazvati osnovom nomotetičkih istraživanja, npr. ekonomskih modela), dok je Njemačka historijska škola tvrdila da se ponašanje može smisleno opisati samo u vlastitom povijesnom kontekstu, pa je traganje za općim zakonitostima ponašanja besmisleno (danas bismo to mogli nazvati obranom ideografskih istraživanja - npr. studija slučaja). Implicitno je austrijski stav prevladao kroz čitavi tijek mainstream, neoklasič- 
se može pod oportunim pretpostavkama matematički modelirati, nadvladao svoju alternativu jednostavnog i mjerljivog agregata.

\section{6) Stanje mainstream ekonomske znanosti krajem 20. i početkom 21. stoljeća: pojedinačno i agregatno u primjeni}

U prošlim odjeljcima prikazano je kako se mainstream u odnosu na stare kejnzijanske osnove višestruko diferencirao (opća ravnoteža, dugi rok, adaptivna i savršena racionalnost). U ovom ću odjeljku nastojati procijeniti takvu slobodnotržišno orijentiranu ekonomsku znanost u primjeni, s obzirom na dileme rezolucije i kompozicije. U tom je kontekstu korisno upozoriti na slavni kriterij korisnosti teorije, koji je sadržan u jednom od najpoznatijih i najutjecajnijih Friedmanovih eseja. Milton Friedman je u "Methodology of Positive Economics" argumentirao da manjak realističnosti ne ograničava korisnost nekog pristupa (Friedman, 1953/1966). Savršena realističnost neke teorije zapravo bi je učinila potpuno beskorisnom za opisivanje kompleksne stvarnosti jer bi opis formiranja cijena uključivao sve detalje stvarnih događaja zajedno s bojom očiju i kose trgovaca (ibid.: 32). Tako Friedman inzistira na ključnoj distinkciji između "deskriptivne preciznosti", koja može biti izrazito realistična, i "analitičke relevantnosti", koja ne mora biti realistična dok god je korisna (ibid.: 34). Ideal-tipovi poput savršene konkurencije - o kojima neoklasična ekonomija ovisi - ne služe kao opis, već kao analitički fokus na ključne elemente odabranog pitanja (ibid.: 36). Friedmanovu argumentaciju treba shvatiti kao obranu redukcionizma koji je upravo postajao implicitan samoj ekonomskoj analizi. Njegovom logikom, modeli mainstream ekonomije ranjivi su zbog vlastitih nerealnih pretpostavki samo ako prestaju biti korisni. Primjena tog kriterija na ekonomski mainstream početka 21. stoljeća zapravo se pokazala krajnje razornom. Može se naime tvrditi da je zbog nepredviđenosti kriza iz 2008/2009. razvijeni svijet zatekla nespremnim, a uspjeh antikrizne politike pokazao se izuzetno ograničenim.

Postoji logička veza između pristupa recesijama i pristupa tržištu: ukoliko je tržište po definiciji racionalno i efikasno (kao kod slobodnotržišnih pristupa), za rješavanje kriza dovoljno se pouzdati u racionalnost slobodnog tržišta. ${ }^{9}$ Ukoliko je

ne ekonomije, koja svojim modelima traga upravo za općim zakonitostima. No kejnzijansko inzistiranje na agregatima i kratkom roku proučavanja nužnim je činilo traganje za konkretnim povijesnim podacima i njihovu praktičnu upotrebu u državnom intervencionizmu, a takav je fokus očitim činio povijesna odstupanja od dugoročne uprosječene logike modela na kojima se zasnivala neoklasična ekonomija.

${ }^{9}$ U generaciji koja formulira mikroekonomiju jedino Jevons pokazuje interes za ekonomske krize i pripisuje ih Sunčevim pjegama, a ne tržištu (Jevons, 1878). Hayek, dobro je poznato, neminovnost kriza vidi u suviše jeftinoj cijeni novca (odnosno u oscilacijama tržišne i neutralne 
tržište manjkavo pa nije uvijek u ravnoteži ili na putu prema optimumu, moramo stvoriti više manevarskog prostora za intervenciju antikriznim ekonomskim politikama. Postoji i poveznica s izborom samih ekonomskih politika. Slobodnotržišni pristupi od Friedmana nadalje podrazumijevaju preferenciju monetarnog odgovora na krize kao transparentnije i manje invazivne opcije, ako je već ikakav odgovor ekonomskih politika potreban. S druge strane je uz slobodnotržišnu struju ostala i kejnzijanska opcija, koja je usprkos sve sličnijim metodološkim rješenjima ipak zagovarala i moguću fiskalnu intervenciju. Temelj odluka o fiskalnoj politici jest odnos između razočaravajućeg stanja u gospodarskoj aktivnosti (rast BDP-a) i rasta javnog duga. Obje se struje slažu u tome da je rast poželjan, ali kejnzijanska struja vidi rješenje recesije u poticajnom povećanju duga, a slobodnotržišna u njegovom smanjenju. ${ }^{10}$

Naime, dok je fiskalna konsolidacija tijekom perioda normalnog rasta možda hvalevrijedna, u recesiji vrijede drugačija pravila. Tako će se Blanchard et alii (2010) među ostalim zalagati za ostvarenje fiskalnog manevarskog prostora (smanjenja javnog duga) upravo kako bi se omogućili potrebni fiskalni poticaji u kontekstu šokova agregatne potražnje. Mjere štednje nas možda očekuju nakon izlaska iz recesije, ali u kontekstu lošeg rasta mogu imati katastrofalne posljedice. Neadekvatna javnopolitička antikrizna rješenja (a naročito okrenutost mjerama štednje u recesijskim godinama) našla su se na udaru mnogih kejnzijanski inspiriranih autora koji im zamjeraju nepotrebno smanjenje mogućnosti rasta. Naime, nakon kratko-

prirodne kamatne stope) i u krizama vidi poželjno stanje tržišta koje na taj način razrješava nakupljene poslovne pogreške (Hayek, 1933). Kao što je pokazano u prethodnom odjeljku, RBC teorija kao mainstream pristup krizama krajem 20. i početkom 21. stoljeća pak vidi krize kao racionalnu reakciju tržišta (odnosno pojedinih aktera koji ga sačinjavaju) na egzogene šokove. U svakom slučaju, teorijsko uzdizanje tržišta (i racionalnosti pojedinca kao osnovnoga građevnog elementa tržišta) ima tendenciju komplementarnosti s opuštenim teorijskim odnosom prema ekonomskim krizama.

${ }_{10}$ Temeljni je praktični izazov, koji može usmjeriti fiskalnu politiku u praksi, procjena veličine fiskalnog multiplikatora, odnosno konačnog odraza svih daljnjih transakcija koje slijede iz inicijalnog rashoda. Ukoliko je multiplikator nizak, javni rashodi nemaju velik učinak na BDP, te je potpuno nelogično zaduživati se kako bi se zadržala razina javnih rashoda. Istom logikom, mjere štednje ne mogu pretjerano naštetiti ekonomskom rastu. Slobodnotržišna strana procjenjuje multiplikatore niskima, pa čak i negativnima kroz koncept ekspanzivne štednje (Alesina i Ardagna, 1998, 2010; Alesina, Favero i Giavazzi, 2015). Čim države fiskalnom konsolidacijom stabiliziraju razine javnih dugova, racionalni investitori će zbog novostečenog povjerenja u makroekonomsko okružje štednju nagraditi masivnim priljevima kapitala, koji će ponovno podignuti investicijsku potražnju i potaknuti rast. S druge strane, ako je multiplikator razmjerno visok, nastupa kejnzijanska logika nastavljanja s velikim javnim rashodima, čak i ako podrazumijevaju deficitarno trošenje. Isto tako, u tom je slučaju pogubno rezati rashode jer će odraz na rast BDP-a biti znatan. 
trajnog i donekle kejnzijanskog prihvaćanja potrebe za fiskalnim poticajima nakon krize 2008/2009, mainstream se decidirano okrenuo mjerama štednje, što je posebno naštetilo europskoj periferiji - uz niz znanstvenih protesta s kejnzijanske strane rasprave (Krugman, 2012; Stiglitz, 2013, 2016; Blyth, 2015; Eichengreen, 2015). Temeljni je problem nametanje fiskalne konsolidacije svim državama članicama EU-a istovremeno (primjerice Paktom o stabilnosti i rastu te pripadajućom Procedurom prekomjernog deficita - vidjeti i Lučev, 2014). Tako se iz kejnzijanske perspektive produbljuje kriza jer se smanjuje agregatna potražnja u svim dijelovima međusobno isprepletenog ekonomskog bloka, a naročito su pogođena najosjetljivija periferna gospodarstva.

Stiglitz (2018) kritizira makroekonomski mainstream kao preopterećen DSGE modelima s krivim pretpostavkama. U skladu s analizom u ovom tekstu Stiglitz smatra da DSGE modeli nisu zbog vlastitih osnova ni mogli predvidjeti sistemsku krizu, a isto tako nisu mogli ponuditi ni adekvatne policy preporuke za njezino prevladavanje. Ključni su problemi upotreba racionalnih reprezentativnih agenata i nemogućnost predviđanja financijske krize zbog neadekvatnog pristupa mogućnosti frikcija u financijskom sustavu. Takvoj kritici Christiano, Eichenbaum i Trabandt (2018) prigovaraju stanovitu anakronost. Suvremeni modeli kakvi se pojavljuju tijekom 21. stoljeća često se uspješno nose s heterogenošću agenata (dakle ne ovise o rezoluciji na reprezentativne racionalne agente) financijskim frikcijama, pa čak i velikim šokovima. S druge je strane točno da problemi financijskog sektora nisu bili predviđeni zbog ovisnosti o povijesnim podacima koji su značili da su modeli prilagođeni periodu ekonomske povijesti nakon Drugog svjetskog rata, odnosno eri bez velikog utjecaja financijskih kriza na realne krize (ibid.: 125). Uz to ovi autori ne predviđaju ni mogućnost da bi postojeći i višestruko popravljeni DSGE modeli mogli predvidjeti iduće krize (ibid.: 136). Blanchard (2018) u tom smislu priznaje ozbiljne nedostatke DSGE modela, ali i upozorava na mogućnost upotrebe tih modela uz one primjerenije funkcijama predviđanja ili policy savjetovanja. Ako smatramo da je predviđanje kriza i formuliranje antikriznih politika jedna od važnih uloga makroekonomije, Friedmanovom se logikom može osporiti upotrebljivost trenutačnog mainstreama. Autori poput Stiglitza skloni su taj nedostatak pripisati upravo DSGE modelima i njihovim ograničenjima (koja se dobrim dijelom svode na njihovu rezolutivnu prirodu). Nešto se optimističniji zaključak može donijeti o njihovim sposobnostima za poboljšanja ili barem za usporedno korištenje alternativnim modelima. U obje varijante ostaje nam činjenica isprepletenosti pitanja makroekonomije i njezinih microfoundations (rezolucija-kompozicija) kao fundamentalne metodološke osnove današnje ekonomije i njezine upotrebljivosti.

Vrijedi zamijetiti da diferenciranje pristupa na temelju kapitalnoga metodološkog izbora između agregata i individualizma nalazi odjek i u međunarodnoj poli- 
tičkoj ekonomiji (MPE). MPE je sve zreliji ${ }^{11}$ interdisciplinarni žanr istraživanja, $s$ počecima u 1970-ima, koji se bavi međunarodnim političko-ekonomskim pitanjima, odnosno "međuodnosom privatne i javne moći u alokaciji oskudnih resursa" (Ravenhill, 2011: 21). ${ }^{12}$ MPE dakle logički uvelike ovisi o školama i pristupima u kontekstu politologije i ekonomije, a njihove brojne permutacije stvaraju strukturu koja je notorna po svojoj raznolikosti, ${ }^{13}$ pa neki komentatori govore čak i o šizoidnosti MPE (Cohen, 2014: 1). U MPE se mogu pronaći jasni odjeci razvoja i kritika ekonomije prikazanih u ovom tekstu - naročito u podjelama pristupa unutar MPE koje svoje ishodište traže u metodi, a ne u ideologiji. Murphy i Nelson (2001) tako tvrde da je urednička politika u najboljim MPE časopisima u SAD-u i UK zapravo stvorila raznovrsne metodološke pravce (koje nazivaju IO škola ${ }^{14}$ i Britanska škola). Na takav će zaključak doći i Benjamin Cohen (Cohen, 2007; 2008) koji opisuje metodološku transatlantsku razdjelnicu između Britanske i Američke škole. Dok se Britanska škola orijentira prvenstveno normativno te se heterodoksno bavi socijalnim konstruktima, Američka inzistira na pozitivnoj znanstvenoj rigoroznosti naslonjenoj na racionalni izbor i metodološki individualizam, često modelirajući države po uzoru na atomističke aktere (vidjeti i Cohen, 2014; Watson, 2011). Drugim riječima, anglofoni znanstveni prostor u MPE izrazio je odjeke dileme o ispravnoj jedinici analize koja je već opisana u kontekstu razvoja ekonomske znanosti. Američka je škola tako kao jedan od dva stila normalne MPE znanosti od ekonomskog mainstreama čvrsto prigrlila (rezolutivnu) redukciju na racionalnog pojedinca (ponekad analogijom prerušenog u državu) kao jedinog prihvatljivog aktera. Ne čudi dakle da se i Američkoj školi MPE može zbog rizičnog redukcionizma (te očitih propusta u rezultatima, poput nemogućnosti predviđanja krize 2008) prigovoriti kako su "njezini propusti podjednako vrijedni pažnje kao i njezina postignuća" (Cohen, 2014: 33).

${ }^{11}$ Samim znanstvenim početkom ponekad se smatra članak Susan Strange (1970) "International Economics and International Relations: A Case of Mutual Neglect" (Cohen, 2007). Autori koji se preferiraju usredotočiti na organizacije vjerojatno će u potrazi za početkom uputiti na uspostavu International Political Economy Group godinu kasnije (pr. Murphy i Nelson, 2001). Nekad uobičajena ocjena o MPE kao relativno novom području istraživanja očito je sve manje primjerena, budući da će 2020. ili 2021, ovisno o interpretaciji, MPE slaviti pola stoljeća postojanja.

12 Ili jednom klasičnom definicijom: "recipročnom i dinamičnom interakcijom u međunarodnim odnosima između težnje za bogatstvom i težnje za moći” (Gilpin, 1975: 43 u Cohen, 2008: 16).

${ }^{13}$ Prije kraja Hladnog rata uloga ideologije u znanstvenim pristupima nešto je vidljivija, pa tada nastaje i klasična Gilpinova ideološka podjela pristupa MPE. Robert Gilpin 1970-ih govori o tri škole: liberalizmu, merkantilizmu i marksizmu, a nešto kasnije (1987), s blagim preimenovanjem, o liberalizmu, nacionalizmu i marksizmu.

${ }^{14}$ Prema International Organization, ključnom znanstvenom časopisu za američki metodološki pravac MPE. 
U vrijeme dovršavanja ovog teksta (svibanj 2020) recesija izazvana mjerama ograničavanja pandemije Covid-19 tek se razvija. U ovom trenutku čini se da će ta recesija biti izrazito oštra, pa tako MMF u 2020. prognozira kontrakciju BDP-a od $-3 \%$ na svjetskoj razini, $-5,9 \%$ u SAD-u, $-7,5 \%$ u eurozoni i $-9 \%$ u Hrvatskoj (IMF, 2020: 5-6; 21). Fiskalni odgovor na ovu situaciju je u SAD-u bio iznimno brz i iznimno snažan pa je, dok još razmjeri nisu bili ni poznati, donesen zakon o fiskalnom poticaju bez povijesnog presedana u veličini (2000 milijardi USD) ili opsegu pokrivenih aktivnosti (Cochrane i Stolberg, 2020). Čak se i štedljiva Njemačka podjednako brzo odvažila na zaokret u dotadašnjoj politici i odobrenje deficita u iznosu 4\% BDP, što je mnogo manji iznos od SAD-a; spremnost na takav potez također je indikativna za ozbiljno shvaćanje problema ("Money for all”, 2020). Veća spremnost upotrebe fiskalne politike kao odgovora na krizu rezultat je nekoliko kontekstualnih čimbenika. Prvi je svakako izostanak povratka monetarne politike na normalno stanje, budući da je permanentni ostatak prošle krize u SAD-u i u eurozoni efikasna antikrizna politika s vrlo malim kamatnim stopama. Tako je uvelike preskočen uobičajeni prvi korak u izboru ekonomskih politika te se potraga za antikriznim politikama odmah okrenula fiskalnoj politici. Drugi je očita činjenica da do recesije ne dolazi iz tržišnih, već iz političkih razloga. Proizvodnja i prijevoz ograničeni su epidemiološki inspiriranim odlukama. Samim time implicitno uvjerenje u sposobnost tržišta da se samo oporavi ne predstavlja prepreku ozbiljnom shvaćanju recesije, pa se bez značajnog otpora može pristupiti potrazi za antikriznim politikama. Tek treći može biti nada da su razorne kritike stanja ekonomskog mainstreama i odabranih ekonomskih politika tijekom prošle krize urodile plodom.

\section{7) Zaključak}

Dag Strpić je u svojoj analizi snažno naglasio odlučujuću važnost i teorijsku produktivnost rezolutivno-kompozitivne metode. U tekstu je pokazano da je upotreba osnovnih elemenata te metode svrhovita kao uporište analize povijesti ekonomske misli. Najprije su pokazane osnovne konture stiliziranih pomaka u paradigmama ekonomske misli (neoklasična ekonomija - kejnzijanska ekonomija - slobodnotržišna paradigma) koji u svjetlu naše reinterpretacije dobivaju strukturu rezolucijekompozicije-rerezolucije. Potom smo u tome svjetlu protumačili razdoblje "nakon Hayeka". Rječnikom Macphersona i Strpića, radi se o privremenom periodu dominacije kompozitivnog elementa, odnosno agregativnih mjerenja koja su uvedena s Keynesovom verzijom makroekonomije. Zatim je pristupljeno proučavanju recepcije Keynesa u mainstream kroz neoklasičnu sintezu (također nazvanu i bastardiziranim kejnzijanizmom) i kroz osnovne metodološke dileme koje je ona pretpostavljala (agregati ili ravnoteže kao osnovne konceptualizacije makroekonomije te učinci upotrebe dugog roka na mikroekonomske efekte tržišta, makroekonomske 
ishode i odnos nezaposlenosti i inflacije). Kroz te smo dileme mogli pratiti i komplementarnost upotrebe dugog roka $u$ analizi, pretpostavljene racionalnosti aktera $i$ optimalnih slobodnotržišnih rezultata. Na taj je način znanstveno dozrela paradigmatska smjena Keynesa Friedmanovim slobodnotržišnim idejama, koju smo popratili u odjeljku koji se bavi stanjem ekonomske znanosti na kraju 20. i početku 21. stoljeća, odnosno Lucasovim zaoštravanjem slobodnotržišne paradigme, kao i dovršenim oblikom tog idejnog sklopa u okviru "teorije realnih poslovnih ciklusa". No ponovna dominacija rezolutivnog elementa (slobodnotržišna paradigma) koji nastoji konstituirati ideju samoregulativnog tržišta oko savršeno racionalnog pojedinca dovodi nas u prave poteškoće: redukcija na savršeno racionalnog pojedinca (rezolutivni manevar) ne može konstituirati veću cjelinu kompozitivno ukoliko je ta redukcija nerealistična na način koji sakati samu korisnost teorije. Stoga je, zaključno, otvoreno i pitanje primjene tih ideja na predviđanje kriza i formuliranje ekonomskih politika u odgovoru na njih.

\section{LITERATURA}

Akerlof, G. A. i Shiller, R. J. (2009). Animal Spirits: How Human Psychology Drives the Economy, and Why It Matters for Global Capitalism. Princeton University Press.

Alesina, A. i Ardagna, S. (1998). Tales of fiscal adjustment. Economic Policy, (13) 27: 487-545.

Alesina, A. i Ardagna, S. (2010). Large changes in fiscal policy: taxes versus spending. Tax Policy and the Economy, (24) 1: 35-68.

Alesina, A., Favero, C. i Giavazzi, F. (2015). The output effect of fiscal consolidation plans. Journal of International Economics, 96, S19-S42.

Archibald, G. C. (2018). Monopolistic Competition, u: G. Jones (ur.): The New Palgrave Dictionary of Economics. Palgrave Macmillan, 9088-9093.

Arrow, K. J. i Debreu, G. (1954). Existence of an equilibrium for a competitive economy. Econometrica: Journal of the Econometric Society, 265-290.

Assenmacher, K. (2017). Bridging the gap between structural VAR and DSGE models, u: R. S. Gürkaynak i C. Tille (ur.): DSGE Models in the Conduct of Policy: Use as Intended. CEPR Press, 23-30.

Babić, M. (2015). Ekonomija: Uvod u analizu i politiku (3. izd.). Plejada.

Backhouse, R. E. (2002). The Penguin History of Economics. Penguin Books.

Bénassy, J. (2018). Dynamic Models with Non-clearing Markets, u: G. Jones (ur.): The New Palgrave Dictionary of Economics. Palgrave Macmillan, 3124-3133. 
Blanchard, O. (1991). Neoclassical Synthesis, u: J. Eatwell, M. Milgate i P. Newman (ur.): The World of Economics. Macmillan, 504-510.

Blanchard, O. (2018). On the future of macroeconomic models. Oxford Review of Economic Policy, (34) 1-2: 43-54.

Blanchard, O., Dell'Ariccia, G. i Mauro, P. (2010). Rethinking Macroeconomic Policy. Journal of Money, Credit and Banking, 42: 199-215.

Blaug, M. (2003). The Formalist Revolution of the 1950s. Journal of the History of Economic Thought, (25) 2: 145-156.

Blyth, M. (2015). Austerity: The history of a dangerous idea. Oxford University Press.

Chamberlin, E. H. (1933/1962). Theory of Monopolistic Competition: A Re-orientation of the Theory of Value. Oxford University Press.

Chang, H. J. (2014). Economics: The User's Guide: A Pelican Introduction. Penguin UK.

Christiano, L. J., Eichenbaum, M. S. i Trabandt, M. (2018). On DSGE models. Journal of Economic Perspectives, (32) 3: 113-140.

Cochrane, E. i Stolberg, S. G. (2020). \$2 Trillion Coronavirus Stimulus Bill Is Signed Into Law. New York Times, 27. ožujka. Dostupno na https://www.nytimes.com/ 2020/03/27/us/politics/coronavirus-house-voting.html

Cohen, B. J. (2007). The Transatlantic Divide: Why are American and British IPE so Different?. Review of International Political Economy, (14) 2: 197-219.

Cohen, B. J. (2008). International Political Economy: An Intelectual History. Princeton University Press.

Cohen, B. J. (2014). Advanced Introduction to International Political Economy. Edward Elgar Publishing.

Chang, H. J. (2014). Economics: The User's Guide. Bloomsbury Publishing USA.

Dasgupta, P. (2002). Modern economics and its critics, u: U. Mäki (ur.): Fact and Fiction in Economics. Cambridge University Press, 57-89.

De Vroey, M. R. (2010). Lucas on the Lucasian transformation of macroeconomics: An assessment. IRES Discussion paper.

Dixon, H. D. (2018). New Keynesian Macroeconomics, u: G. Jones (ur.): The New Palgrave Dictionary of Economics. Palgrave Macmillan, 9493-9500.

Dornbusch, R., Fischer, S. i Startz, R. (2017). Macroeconomics (13. izd.). McGraw-Hill.

Eichengreen, B. (2015). Hall of mirrors: The great depression, the great recession, and the uses - and misuses - of history. Oxford University Press.

Fine, B. i Dimakou, O. (2016). Macroeconomics: A Critical Companion. Pluto Press.

Foley, D. K. (2014). Varieties of Keynesianism. International Journal of Political Economy, (43) 1: 4-19. 
Friedman, M. (1953/1966). The Methodology of Positive Economics, u: Essays in Positive Economics. University of Chicago Press, 3-16.

Friedman, M. (1968). The Role of Monetary Policy. The American Economic Review, (58) 1: 1-17.

Friedman, M. (1976). Nobel lecture: inflation and unemployment. Dostupno na https:// assets.nobelprize.org/uploads/2018/06/friedman-lecture-1.pdf

Friedman, M. i Goodhart, C. A. E. (1975/2003). Money, inflation and the constitutional position of the central bank. Institute of Economic Affairs.

Friedman, M. i Schwartz, A. J. (1963). A Monetary History of the United States, 18671960. Princeton University Press.

Gilpin, R. (1987). The Political Economy of International Relations. Princeton University Press.

Hartley, J. E. (1997). The Representative Agent in Macroeconomics. Taylor and Francis. Hayek, F. A. (1933). Monetary Theory and the Trade Cycle. Sentry Press.

Hicks, J. R. (1937). Mr. Keynes and the "Classics"; A Suggested Interpretation. Econometrica: Journal of the Econometric Society, 147-159.

Hoover, K. D. (2008). Does Macroeconomics Need Microfoundations? (3. izd.), u: D. M. Hausman (ur.): The Philosophy of Economics: An Anthology. Cambridge University Press, 315-333.

IMF (2020). World Economic Outlook, Chapter 1: The Great Lockdown. Dostupno na https://www.imf.org/en/Publications/WEO/Issues/2020/04/14/weo-april-2020

Janssen, M. (2018). Microfoundations, u: G. Jones (ur.): The New Palgrave Dictionary of Economics. Palgrave Macmillan, 8744-8750.

Jevons, W. S. (1878). Commercial Crises and Sun-Spots. Nature, 19: 33-37.

Keynes, J. M. (1936/2013). The General Theory of Employment, Interest, and Money. Cambridge University Press.

Keynes, J. M. (1937). The general theory of employment. The Quarterly Journal of Economics, (51) 2: 209-223.

Kovač, B. (2018). Političko-ekonomski ogledi. Nacionalna zajednica Crnogoraca Hrvatske/Disput.

Krugman, P. (2012). End this depression now!. W. W. Norton \& Company.

Kydland, F. E. i Prescott, E. C. (1982). Time to build and aggregate fluctuations. Econometrica: Journal of the Econometric Society, 1345-1370.

Leijonhufvud, A. (1973). Life Among the Econ. Western Economic Journal, (11) 3: 327337.

Ljungqvist, L. (2018). Lucas Critique, u: G. Jones (ur.): The New Palgrave Dictionary of Economics. Palgrave Macmillan, 8045-8049. 
Lucas, R. (1972). Expectations and the Neutrality of Money. Journal of Economic Theory, (4) 2: 103-124.

Lucas, R. (1976a). Econometric policy evaluation: A critique. Carnegie-Rochester Conference Series on Public Policy, (1) 1: 19-46.

Lucas, R. (1976b). Understanding business cycles. Carnegie-Rochester Conference Series on Public Policy, 5: 7-29.

Lucas, R. (1978). Unemployment Policy. The American Economic Review, (68) 2: 353357.

Lucas, R. (1987). Models of Business Cycles. Basil Blackwell.

Lucas, R. (2003). Macroeconomic priorities. The American Economic Review, (93) 1: $1-14$.

Lučev, J. (2014). Duhovi kapitalizma i mjere štednje. Politička misao, (51) 4: 26-40.

Lučev, J. i Babić, Z. (2013). Tipovi kapitalizma, ekspanzija neoliberalizma i socijalni učinci u baltičkim zemljama, Sloveniji i Hrvatskoj: komparativni pristup. Revija za socijalnu politiku, (20) 1: 1-20.

Macpherson, C. B. (1962). The Political Theory of Possessive Individualism: Hobbes to Locke. Oxford University Press.

Mankiw, N. G. (2017). Principles of Macroeconomics (8. izd.). Cengage Learning.

"Money for all” (2020). The Economist, 28. ožujka, str. 26.

Murphy, C. N. i Nelson, D. R. (2001). International political economy: a tale of two heterodoxies. The British Journal of Politics \& International Relations, (3) 3: 393-412.

Phillips, A. W. (1958). The Relation Between Unemployment and the Rate of Change of Money Wage Rates in the United Kingdom, 1861-1957. Economica, (25) 100: 283-299.

Ravenhill, J. (2011). The Study of Global Political Economy, u: J. Ravenhill (ur.): Global Political Economy. Oxford University Press, 3-28.

Robinson, J. (1933/1969). The Economics of Imperfect Competition. Macmillan.

Robinson, J. (1972). The Second Crisis of Economic Theory. The American Economic Review, (62) 2: 1-10.

Romer, D. (1993). The new Keynesian synthesis. Journal of Economic Perspectives, (7) 1: $5-22$.

Samuelson, P. A. i Nordhaus, W. D. (2009). Economics (19. izd.). McGraw-Hill.

Schumpeter, J. A. (1975). Povijest ekonomske analize I/II. Informator.

Skarbek, D. B. (2009). F. A. Hayek's influence on Nobel Prize winners. The Review of Austrian Economics, (22) 1: 109-112.

Snowdon, B. i Vane, H. R. (2005). Modern Macroeconomics: Its Origins, Development and Current State. Edward Elgar. 
Stiglitz, J. E. (2013). The price of inequality: How today's divided society endangers our future. W. W. Norton.

Stiglitz, J. E. (2016). The Euro, and its threat to the future of Europe. W. W. Norton.

Stiglitz, J. E. (2018). Where modern macroeconomics went wrong. Oxford Review of Economic Policy, (34) 1-2: 70-106.

Strange, S. (1970). International Economics and International Relations: A Case of Mutual Neglect. International Affairs (Royal Institute of International Affairs 1944-), (46) 20: 304-315.

Strpić, D. (1998). Promjena. Politička i političko-ekonomska promjena od Hobbesa do Hayeka. Politička misao.

Strpić, D. (2010). Karl Marx i politička ekonomija Moderne. Nacionalna zajednica Crnogoraca Hrvatske/Disput.

Strpić, D. (2015). Prema Novoj političkoj ekonomiji. Disput.

Strpić, D. (2017). Robna proizvodnja i udruženi rad u Marxovoj kritici političke ekonomije. Disput.

Watson, M. (2011). The Historical Roots of Theoretical Traditions in Global Political Economy, u: J. Ravenhill (ur.): Global Political Economy. Oxford University Press, 29-66.

\author{
Josip Lučev \\ DEVELOPMENT OF MACROECONOMICS \\ AND THE RESOLUTIVE-COMPOSITIVE METHOD
}

\begin{abstract}
Summary
The objective of this text is to demonstrate the plausibility of the use of the Hobbesian resolutive-compositive method as a base for analysis of the history of modern economic thought, and particularly of macroeconomics. Firstly, the importance of the resolutive-compositive method for the works of Dag Strpic is explained. Secondly, the text shows the basic tenets of stylized shifts in economic paradigms (neoclassical economics - Keynesian economics free-market paradigm) which are reinterpreted here as resolution-composition-reresolution. An interpretation of the intellectual history "after Hayek" is also offered, focusing on Keynesian macroeconomics based on aggregates. The text then explains neoclassical synthesis and the elementary methodological dilemmas it represented through its long integration of Keynes into the mainstream (including the choice of aggregates or aggregated individuals as the basis of macroeconomics). The text follows the complementary relationship of the effects of long-run analysis, the assumption of rationality and optimal free-market results. The state of the economic mainstream at the end of
\end{abstract}


the $20^{\text {th }}$ century and the beginning of the $21^{\text {st }}$ century is then shown - particularly the Lucasian methodological upgrade of Friedman's ideas and the developed form of this conceptual framework within the Real Business Cycles theory. The renewed dominance of the resolutive element (free-market paradigm) - constituting the idea of a self-regulating market around the perfectly rational individual - leads us into a challenging situation. The reduction to a perfectly rational individual (resolutive maneuver) should not constitute a larger (compositive) whole if such a reduction is unrealistic to an extent that dramatically limits the very usefulness of the theory. Therefore, the conclusion raises the question of applying this idea of predicting crises and formulating responses to them.

Keywords: Macroeconomics, History of Economic Analysis, Rationality, Aggregation Problem, Resolutive-Compositive Method, Strpić

Josip Lučev je asistent na Fakultetu političkih znanosti Sveučilišta u Zagrebu.

Kontakt: Josip Lučev, Fakultet političkih znanosti, Lepušićeva 6, 10000 Zagreb. E-mail: jlucev@gmail.com 